\title{
Lack of Relationship Between Susceptibility to Common Root Rot and Drought Tolerance Among Several Closely Related Wheat Lines
}

\author{
G. Piccinni and C. M. Rush, Texas A\&M University, Texas Agricultural Experiment Station, P.O. Drawer 10, \\ Bushland 79012; K. M. Vaughn, Paymaster Cotton-seed, 1301 East 50th Street, Lubbock, TX 79404; and M. D. \\ Lazar, Texas A\&M University, Texas Agricultural Experiment Station, P.O. Drawer 10, Bushland 79012
}

\begin{abstract}
Piccinni, G., Rush, C. M., Vaughn, K. M., and Lazar, M. D. 2000. Lack of relationship between susceptibility to common root rot and drought tolerance among several closely related wheat lines. Plant Dis. 84:25-28.

Common root rot caused by Bipolaris sorokiniana is a disease of wheat associated with plant stress. Three cultivars (Siouxland, TAM 200, and TAM 107) and several hard red winter wheat lines closely related to TAM 107, but known to differ with respect to drought tolerance, were included in a 2-year dryland field study to evaluate whether observed variation in drought tolerance was associated with susceptibility to $B$. sorokiniana. Untreated seed of each entry or seed treated with imazalil was planted in soil naturally infested with $B$. sorokiniana. Plants were evaluated at jointing and at harvest. Disease incidence and severity, number of plants, number of heads, and grain weight per meter were evaluated. Grain weight and number of heads of individual plants were recorded in order to correlate disease rating of each plant with yield components. Plot yield and test weight also were measured. There were significant entry by seed treatment interactions for number of heads per plant, grain weight per plant, and grain weight per meter. A year by treatment interaction was found for the jointing disease index, and plants grown from seed treated with imazalil had a significantly lower disease index than those grown from nontreated seed. Observed drought tolerance among the three varieties and eight closely related plant introductions was not associated with disease susceptibility to common root rot.
\end{abstract}

In the Southern Great Plains, hard red winter wheat is widely grown under various irrigation regimes, ranging from dryland to full irrigation production. Annual precipitation in this area is irregular, ranging between $380 \mathrm{~mm}$ (15 in) and $580 \mathrm{~mm}$ (23 in). In the Texas Panhandle, the average precipitation during the wheat-growing season is approximately $250 \mathrm{~mm}$ (10 in), or about one-third of the evapotranspiration (ET) requirement for wheat grown under adequate irrigation for high yield (4). Drought stress is often a serious problem for wheat production in this region.

Drought may exacerbate development of certain diseases associated with plant stress (16). One such disease is common root rot of wheat caused by Bipolaris sorokiniana (16). This fungus infects the stems, crowns, and roots of wheat plants (14). Typical symptoms of common root rot are easily visible at the subcrown internode, which becomes dark brown to black when infected. One of the primary effects of common root rot of wheat is a reduction in crown and seminal roots, which are associ-

Corresponding author: G. Piccinni

E-mail: g-piccinni@tamu.edu

Accepted for publication 6 September 1999.

Publication no. D-1999-1101-02R

(C) 2000 The American Phytopathological Society ated with tiller development and water uptake (6). Yield losses due to common root rot have been estimated at between 6 and $44 \%$ depending on cultivar, planting date, and location $(1,15,17)$.

In recent years, specific wheat lines developed in regional trials throughout the Great Plains (7) have been identified that exhibit a degree of drought tolerance. Because of the near ubiquitous occurrence of B. sorokiniana in wheat field soils (12), it is probable that these lines were developed in the presence of this pathogen. Therefore, the observed drought tolerance of these lines could be associated with lower susceptibility to common root rot. With this in mind, a study was initiated to determine whether the wheat lines in question varied in their susceptibility to common root rot and to determine if any correlation exists between disease severity and yield components of these hard red winter wheat lines. A preliminary report has been published (9).

\section{MATERIALS AND METHODS}

Research was conducted at the Texas Agricultural Experiment Station in Bushland in a field continuously cropped to wheat for over 5 years and naturally infested with B. sorokiniana. Three wheat cultivars, TAM 200, Siouxland, and TAM 107 , and eight genotypes closely related to TAM 107 (Table 1) were planted in fourrow plots, each $4.5 \mathrm{~m}$ long and $1.5 \mathrm{~m}$ wide.
The three cultivars had been evaluated for susceptibility to common root rot (10), and the closely related genotypes were selected according to previously identified differences in drought susceptibility (7). Seed of each entry were treated with imazalil, 1-[2(2,4-dichlorophenyl)-2-(2-propenyloxy)ethyl]- $1 H$-imidazole, at the rate of $14.8 \mathrm{ml}$ $(0.5 \mathrm{fl} \mathrm{oz})$ of product per $45.35 \mathrm{~kg}(100 \mathrm{lb})$ of seed (10) or left untreated. Each entryseed treatment combination was replicated eight times, resulting in 176 plots. These were arranged in a split-plot design with entry representing main plots and seed treatment representing subplots. Wheat was planted on 20 September 1993 and 6 October 1995.

Stand counts were taken approximately 4 weeks after planting from a 1-m subplot within each plot. Disease evaluations were conducted at jointing and at harvest. Approximately five plants from each of the four rows were sampled for the jointing disease evaluation. At harvest, two 0.5-m subsamples from the two center rows were pulled for disease evaluation and singleplant yield determination. The method used to determine disease severity was a modified version of that developed by Ledingham et al. (8). Plants were gently pulled so that the subcrown internode remained attached, and roots were then washed to remove remaining soil and to expose the subcrown internode for visual inspection. Cleaned internodes were analyzed and graded on a scale of 0 to 4 , with plants rated as 0 having no visible symptoms on the subcrown internode, 1 having up to $25 \%$ discoloration, 2 having 26 to $50 \%$ discoloration, 3 having 51 to $75 \%$ discoloration, and 4 having more than

Table 1. Comparisons of name designations of the eight closely related wheat genotypes evaluated in this study

\begin{tabular}{llc}
\hline $\begin{array}{l}\text { Current } \\
\text { designation }\end{array}$ & $\begin{array}{c}\text { Lazar } \\
\text { designation }\end{array}$ & $\begin{array}{c}\text { Drought } \\
\text { tolerance }\end{array}$ \\
\hline PI587029 & TX86A8072 & 1 \\
PI587031 & TXGH10194 & 3 \\
PI587033 & TXGH10440 & 4 \\
PI587027 & TX84A18 & 8 \\
PI587028 & TX86A5606 & 7 \\
PI587032 & TXGH10289 & 5 \\
PI587030 & TX88A6880 & 2 \\
... & TX88A6848 & 6 \\
\hline
\end{tabular}

${ }_{\mathrm{z}}$ Drought tolerance ranking per Lazar et al. (7). $1=$ most tolerant and $8=$ least tolerant. 
$76 \%$ of the subcrown internode discolored. A disease index (DI) was then calculated using the following formula:

$$
D I=\frac{\left[\left(X_{1} \times 1\right)+\left(X_{2} \times 2\right)+\left(X_{3} \times 3\right)+\left(X_{4} \times 4\right)\right]}{\left(X_{0}+X_{1}+X_{2}+X_{3}+X_{4}\right)}
$$

where $X_{0}, X_{1}, X_{2}, X_{3}$, and $X_{4}$ are the numbers of plants having disease ratings of 0 , $1,2,3$, and 4 , respectively.

At harvest, after plants were assigned a disease rating, the number of heads per plant was determined, and heads were threshed to determine grain weight per plant. Plots were harvested with a small plot combine on 20 June 1994 and 7 July 1996, and plot yield and test weight were determined.

Data were analyzed by analysis of variance, and significant treatment differences were separated by Duncan's multiple range test for each dependent variable. Yield and yield components also were correlated to disease index, and Pearson's correlation coefficients were evaluated for significance.

\section{RESULTS}

Environmental conditions were conducive for disease development during each year of the study. During 1993 and 1994, it was relatively dry until February, but precipitation was adequate for grain development thereafter. In 1995 and 1996, 75.4 $\mathrm{mm}$ (2.97 in) of rain fell in September, which allowed for seed germination and crop establishment. However, this was followed by a prolonged period of drought that persisted until harvest.

Significant differences were found in jointing and harvest disease index, number of heads per plant, grain weight per plant, and grain weight per meter between treated and untreated seed and among the 11 entries. Also, there were significant differences in yield and test weight among entries; seed treatment had no effect on these parameters. No significant differences were found between the two crop years of the study for all dependent variables except disease index. For this reason, data from the two crop years were analyzed together for all dependent variables except March disease index. However, because of significant $(P=0.05)$ treatment by entry interactions, data were sorted by seed treatment and entry for all dependent variables except jointing disease index, yield, and test weight.

Nontreated and treated entries had significantly higher disease indices in the 1993-94 crop season than in the 1995-96 season (Table 2). Furthermore, as anticipated, imazalil significantly reduced disease severity in both crop seasons.

Disease ratings for TAM 200 were consistently higher than for Siouxland in both years of the study (Table 3). In the 1995-96 jointing evaluation, only PI587031 and PI587032 had significantly less disease than TAM 200, the susceptible check.
In nontreated plots, Siouxland had significantly more heads per plant than all other cultivars except TAM 200 and PI587033 (Table 4). Entries PI587027 and PI587028, on the other hand, had a significantly lower number of heads per plant. Seed treatment with imazalil increased the number of heads per plant only with PI587027 and TX88A6848, even though it significantly decreased disease severity on every entry.

Mean separations of grain weight per plant among all entries for nontreated seed indicated that Siouxland and PI587033 had the highest grain weight per plant, while TX88A6848 had the lowest. In the imazalil treatment, Siouxland and PI587032 had significantly higher grain weight than TAM 200 (Table 4).

TAM 107, PI587032, PI587028, and TX88A6848 were positively affected by imazalil seed treatment (Table 4). These entries had significantly higher grain weight per plant in the treated seed plots than in the nontreated plots. On the other hand TAM 200, PI587030, and PI587033 had reduced grain weight per plant with imazalil treated seed. PI587031, PI587027, PI587029, and Siouxland were unaffected by seed treatment.

TAM 200 had significantly more heads per meter than all other entries in both treated and nontreated plots (Table 5). Siouxland ranked second in number of heads per meter; however, it did not have significantly more heads than any other cultivar in the imazalil treatment. TAM 200 and Siouxland had significantly higher grain weights per meter than did the other entries, except for PI587027 and PI587033, in the control treatment. In treated plots, PI587032 had significantly higher grain

Table 2. Effect of seed treatment on common root rot disease severity at March and June disease evaluations for the two crop seasons ${ }^{y}$

\begin{tabular}{lccccc}
\hline & \multicolumn{2}{c}{ March disease index } & & \multicolumn{2}{c}{ June disease index } \\
\cline { 2 - 3 } \cline { 5 - 6 } Crop season & Nontreated & Treated & & Nontreated & Treated \\
\hline $1993-94$ & $1.59 \mathrm{~A} \mathrm{a}^{\mathrm{z}}$ & $1.03 \mathrm{~A} \mathrm{~b}$ & & $3.57 \mathrm{~A} \mathrm{a}$ & $3.32 \mathrm{~A} \mathrm{~b}$ \\
$1995-96$ & $0.94 \mathrm{~B} \mathrm{a}$ & $0.70 \mathrm{~B} \mathrm{~b}$ & & $3.55 \mathrm{~A} \mathrm{a}$ & $3.24 \mathrm{~A} \mathrm{~b}$ \\
\hline
\end{tabular}

y Values represent mean of all entries combined.

${ }^{\mathrm{z}}$ Means followed by the same uppercase letter within a column are not significantly different. Means followed by the same lowercase letter within a row for each disease evaluation are not significantly different.

Table 3. Disease ratings for common root rot of wheat comparing entries of nontreated seed at March and June evaluations for the two crop seasons

\begin{tabular}{llllll}
\hline & \multicolumn{2}{c}{ March disease evaluation } & & \multicolumn{2}{c}{ June disease evaluation } \\
\cline { 2 - 3 } \cline { 5 - 6 } Cultivars & $\mathbf{1 9 9 3 - 9 4}$ & $\mathbf{1 9 9 5 - 9 6}$ & & $\mathbf{1 9 9 3 - 9 4}$ & $\mathbf{1 9 9 5 - 9 6}$ \\
\hline TAM 200 & $1.95 \mathrm{~A}$ & $1.29 \mathrm{~A}$ & & $3.70 \mathrm{ABC}$ & $3.40 \mathrm{C}$ \\
PI587030 & $1.82 \mathrm{AB}$ & $1.10 \mathrm{AB}$ & & $3.74 \mathrm{AB}$ & $3.61 \mathrm{ABC}$ \\
PI587031 & $1.60 \mathrm{AB}$ & $0.58 \mathrm{C}$ & & $3.61 \mathrm{BCD}$ & $3.51 \mathrm{C}$ \\
PI587032 & $1.59 \mathrm{AB}$ & $0.71 \mathrm{BC}$ & & $3.78 \mathrm{~A}$ & $3.47 \mathrm{C}$ \\
PI587028 & $1.57 \mathrm{AB}$ & $1.00 \mathrm{ABC}$ & & $3.56 \mathrm{CD}$ & $3.63 \mathrm{ABC}$ \\
PI587033 & $1.57 \mathrm{AB}$ & $0.80 \mathrm{ABC}$ & & $3.57 \mathrm{CD}$ & $3.50 \mathrm{C}$ \\
TX88A6848 & $1.54 \mathrm{AB}$ & $1.10 \mathrm{AB}$ & & $3.75 \mathrm{AB}$ & $3.83 \mathrm{~A}$ \\
PI587027 & $1.53 \mathrm{AB}$ & $0.82 \mathrm{ABC}$ & & $3.50 \mathrm{D}$ & $3.79 \mathrm{AB}$ \\
TAM 107 & $1.49 \mathrm{AB}$ & $1.04 \mathrm{ABC}$ & & $3.75 \mathrm{AB}$ & $3.54 \mathrm{BC}$ \\
PI587029 & $1.45 \mathrm{~B}$ & $0.80 \mathrm{ABC}$ & & $3.61 \mathrm{BCD}$ & $3.62 \mathrm{ABC}$ \\
Siouxland & $1.37 \mathrm{~B}$ & $1.13 \mathrm{AB}$ & & $2.73 \mathrm{E}$ & $3.15 \mathrm{D}$ \\
\hline
\end{tabular}

${ }^{\mathrm{z}}$ Means followed by the same uppercase letter within a column are not significantly different.

Table 4. Number of heads per plant and grain weight per plant comparing entries and seed treatment for the 1993-94 and 1995-96 crop seasons combined

\begin{tabular}{llllll}
\hline & \multicolumn{2}{c}{ No. of heads per plant } & & \multicolumn{2}{c}{ Grain weight per plant $(\mathrm{g})$} \\
\cline { 2 - 3 } \cline { 5 - 6 } Cultivars & Nontreated & Treated & & Nontreated & Treated \\
\hline TAM 200 & $3.61 \mathrm{AB} \mathrm{a}^{2}$ & $2.93 \mathrm{BC} \mathrm{b}$ & & $1.43 \mathrm{CD} \mathrm{a}$ & $1.13 \mathrm{E} \mathrm{b}$ \\
PI587030 & $3.42 \mathrm{BC}$ & $3.07 \mathrm{ABC}$ & & $1.70 \mathrm{~B} \mathrm{a}$ & $1.35 \mathrm{DE} \mathrm{b}$ \\
PI587031 & $2.97 \mathrm{DEF} \mathrm{a}$ & $2.51 \mathrm{D} \mathrm{b}$ & & $1.32 \mathrm{DE}$ & $1.31 \mathrm{DE}$ \\
PI587032 & $3.14 \mathrm{CD}$ & $3.33 \mathrm{~A}$ & & $1.65 \mathrm{BC} \mathrm{b}$ & $2.31 \mathrm{~A} \mathrm{a}$ \\
PI587028 & $2.54 \mathrm{G}$ & $2.73 \mathrm{CD}$ & & $1.03 \mathrm{FG} \mathrm{b}$ & $1.42 \mathrm{CD} \mathrm{a}$ \\
PI587033 & $3.68 \mathrm{AB}$ & $3.36 \mathrm{~A}$ & & $2.08 \mathrm{~A} \mathrm{a}$ & $1.65 \mathrm{BC} \mathrm{b}$ \\
TX88A6848 & $2.68 \mathrm{FG} \mathrm{b}$ & $3.11 \mathrm{AB} \mathrm{a}$ & & $0.88 \mathrm{G} \mathrm{b}$ & $1.26 \mathrm{DE} \mathrm{a}$ \\
PI587027 & $2.47 \mathrm{G} \mathrm{b}$ & $2.75 \mathrm{BCD} \mathrm{a}$ & & $1.24 \mathrm{DEF}$ & $1.37 \mathrm{DE}$ \\
TAM 107 & $2.75 \mathrm{EFG}$ & $2.89 \mathrm{BC}$ & & $1.14 \mathrm{EF} \mathrm{b}$ & $1.61 \mathrm{BC} \mathrm{a}$ \\
PI587029 & $3.05 \mathrm{DE}$ & $2.95 \mathrm{BC}$ & & $1.60 \mathrm{BC}$ & $1.66 \mathrm{BC}$ \\
Siouxland & $3.85 \mathrm{~A} \mathrm{a}$ & $3.43 \mathrm{~A} \mathrm{~b}$ & & $1.95 \mathrm{~A}$ & $1.70 \mathrm{~B}$ \\
\hline
\end{tabular}

${ }^{\mathrm{z}}$ Means followed by the same uppercase letter within a column are not significantly different. Means followed by the same lowercase letter within a row are not significantly different. 
weight per meter than all other cultivars except TAM 200, and TAM 107.

The only significant difference in number of heads per meter was detected in Siouxland, which had more heads in nontreated than in treated plots (Table 5). However, this difference was not reflected in grain weight per meter. TAM 107 was the only entry that had significantly higher grain weight per meter in treated plots than in the nontreated seed plots.

Since no interaction was indicated between seed treatment and cultivar, and no significant seed treatment effect existed for plot yield and test weight, data from treated and nontreated plots were analyzed together. TAM 200 had a significantly higher yield than all other entries except PI587032 (Table 6). TAM 200 also had significantly higher test weight than all other entries, followed by Siouxland, despite the fact that this cultivar ranked last in plot yield. PI587032, which had a plot yield significantly higher than most of the other entries, had the lowest test weight.

Correlation analysis showed no significant relationship between yield components and March or June disease index. Even when data were sorted by entry, correlation coefficients for individual entries were always low and typically not significant.

\section{DISCUSSION}

Common root rot has been reported as a disease of wheat and barley associated with plant stress $(5,11,13)$, and because drought stress is the major constraint for wheat production in the High Plains of Texas, we investigated drought-tolerant wheat lines for susceptibility to common root rot. Lazar et al. (7) showed genotypic variation in drought susceptibility among closely related wheat lines. With the exception of TX88A6848, the seven sister lines that they compared are the same plant introductions used in this study (Table 1). They found that PI587029, PI587031, and PI587033 produced higher dryland yield than TAM 107, while PI587027 and PI587028 produced significantly lower dryland yield than TAM 107. Their results were consistent throughout 1986 to 1991 field trials. In our study, the observed drought tolerance of these plant introductions as determined by multiple yield components was not correlated with resistance to common root rot in terms of plot grain yield.

The effect of common root rot on spring wheat and barley has been the subject of many studies. However, there are few publications addressing the effect of common root rot on hard red winter wheat. Verma et al. (14) determined that the major effect of common root rot on spring wheat was to reduce the number of tillers per plant and, consequently, grain yield. The number of grains per head also was affected. Similar results were indicated by Duczek (2) and Duczek and Jones-Flory (3). They found that spring wheat infected early in the season by $B$. sorokiniana produced fewer tillers than wheat infected later in the season. This also was reflected in yield per plant. They found a positive correlation between number of tillers and yield, and, in many cases, a cultivar effect on yield in diseased plots. In our study, tiller counts were not taken during the growing season, but significant differences in yield among cultivars were observed. Nontreated Siouxland had significantly more heads per plant than all other entries except TAM 200 and PI587033. However, when comparing the number of heads per plant of each entry between treated and nontreated plants, only TX88A6848 and PI587027 had more heads per plant in the treated plots than in the nontreated. This indicated a rather ambiguous plant yield response to imazalil, even though it was very effective in reducing disease severity.

Duczek and Jones-Flory (3) recorded a phenomenon of compensation in barley in which plants with fewer tillers had higher grain weight per tiller. We did not find any relationship between number of heads per plant and grain yield on a per plant basis. In the nontreated control, Siouxland, TAM 200, and PI587033 had significantly more heads than all other entries except
PI587030. Imazalil generally had a negative effect on number of heads per plant. Only TX88A6848 and PI587027 showed a significant increase in number of heads per plant with treated seed. On the other hand, Siouxland, TAM 200, and PI587031 had a significant reduction in number of heads per plant with treated seed. Although this could be an indication of phytotoxicity, a reduction in grain weight per plant in the imazalil treatment was observed only for TAM 200. This suggests that the reduction in number of heads per plant was compensated by heavier seeds. This type of grain weight increase in entries having fewer heads per plant is similar to the observations by Duczek and Jones-Flory (3) with barley. However, in the first year of our study, we also compared the effect of disease rating on grain weight per plant for TAM 200 and Siouxland, susceptible and resistant to common root rot, respectively (Table 7). No significant differences in grain weight among the five classes of disease ratings for either cultivar were indicated.

The results of this study are in general agreement with those obtained by Rush and Mathieson (10). They found that

Table 6. Plot yield and test weight by entry for the 1993-94 and 1995-96 crop seasons combined $^{\mathrm{y}}$

\begin{tabular}{lcl}
\hline Cultivars & $\begin{array}{c}\text { Plot yield } \\
(\mathbf{g})\end{array}$ & $\begin{array}{c}\text { Test weight } \\
\left(\mathbf{k g ~ m}^{-3}\right)\end{array}$ \\
\hline TAM 200 & $1,072.71 \mathrm{~A}^{\mathrm{z}}$ & $818.02 \mathrm{~A}$ \\
PI587030 & $755.59 \mathrm{C}$ & $769.24 \mathrm{E}$ \\
PI587031 & $831.99 \mathrm{C}$ & $772.20 \mathrm{DE}$ \\
PI587032 & $980.20 \mathrm{AB}$ & $764.48 \mathrm{~F}$ \\
PI587028 & $805.29 \mathrm{C}$ & $773.10 \mathrm{DE}$ \\
PI587033 & $768.10 \mathrm{C}$ & $777.35 \mathrm{C}$ \\
TX88A6848 & $747.78 \mathrm{C}$ & $770.27 \mathrm{E}$ \\
PI587027 & $960.86 \mathrm{~B}$ & $777.99 \mathrm{C}$ \\
TAM 107 & $827.59 \mathrm{C}$ & $776.06 \mathrm{CD}$ \\
PI587029 & $752.43 \mathrm{C}$ & $771.81 \mathrm{E}$ \\
Siouxland & $731.29 \mathrm{C}$ & $789.57 \mathrm{~B}$ \\
\hline
\end{tabular}

y Values represent means from treated and nontreated plots.

${ }^{\mathrm{z}}$ Means followed by the same uppercase letter within a column are not significantly different.

Table 7. Relationship between disease category and mean grain weight per plant $(\mathrm{g})$ of the susceptible and tolerant control ment for the 1993-94 and 1995-96 crop seasons combined

\begin{tabular}{lccccc}
\hline & \multicolumn{2}{c}{ No. of heads per meter } & & \multicolumn{2}{c}{ Grain weight per meter $(\mathrm{g})$} \\
\cline { 2 - 3 } \cline { 5 - 6 } Cultivars & Nontreated & Treated & & Nontreated & Treated \\
\hline TAM 200 & $197.83 \mathrm{~A}^{z}$ & $203.17 \mathrm{~A}$ & & $77.50 \mathrm{~A}$ & $77.29 \mathrm{AB}$ \\
PI587030 & $99.00 \mathrm{E}$ & $102.17 \mathrm{C}$ & & $47.99 \mathrm{C}$ & $44.73 \mathrm{C}$ \\
PI587031 & $114.50 \mathrm{DE}$ & $101.33 \mathrm{C}$ & & $50.15 \mathrm{C}$ & $50.24 \mathrm{C}$ \\
PI587032 & $111.50 \mathrm{DE}$ & $132.00 \mathrm{BC}$ & & $56.91 \mathrm{BC}$ & $89.87 \mathrm{~A}$ \\
PI587028 & $138.33 \mathrm{BCD}$ & $118.83 \mathrm{BC}$ & & $54.44 \mathrm{BC}$ & $60.17 \mathrm{BC}$ \\
PI587033 & $127.33 \mathrm{CDE}$ & $116.83 \mathrm{BC}$ & & $70.90 \mathrm{AB}$ & $56.43 \mathrm{BC}$ \\
TX88A6848 & $139.17 \mathrm{BCD}$ & $147.33 \mathrm{~B}$ & & $45.38 \mathrm{C}$ & $58.51 \mathrm{BC}$ \\
PI587027 & $143.50 \mathrm{BC}$ & $138.00 \mathrm{BC}$ & & $70.66 \mathrm{AB}$ & $64.70 \mathrm{BC}$ \\
TAM 107 & $116.50 \mathrm{CDE}$ & $127.33 \mathrm{BC}$ & & $47.69 \mathrm{C} \mathrm{b}$ & $69.34 \mathrm{ABC}$ a \\
PI587029 & $104.50 \mathrm{E}$ & $107.00 \mathrm{C}$ & & $52.02 \mathrm{BC}$ & $57.98 \mathrm{BC}$ \\
Siouxland & $159.00 \mathrm{~B} \mathrm{a}$ & $118.00 \mathrm{BC} \mathrm{b}$ & & $79.37 \mathrm{~A}$ & $56.75 \mathrm{BC}$ \\
\hline
\end{tabular}

${ }^{\mathrm{z}}$ Means followed by the same uppercase letter within a column are not significantly different. Means followed by the same lowercase letter within a row are not significantly different.

\begin{tabular}{ccc}
\hline Disease rating $^{y}$ & TAM 200 & Siouxland \\
\hline 0 & $0.77 \mathrm{~A}^{\mathrm{z}}$ & $1.74 \mathrm{~A}$ \\
1 & $0.82 \mathrm{~A}$ & $1.78 \mathrm{~A}$ \\
2 & $1.18 \mathrm{~A}$ & $2.26 \mathrm{~A}$ \\
3 & $1.31 \mathrm{~A}$ & $1.87 \mathrm{~A}$ \\
4 & $1.27 \mathrm{~A}$ & $1.62 \mathrm{~A}$ \\
\hline
\end{tabular}

y Individual plants were given a disease rating of 0 to 4 , with $0=$ no symptoms and $4=$ more than $75 \%$ discoloration of the subcrown internode, and then grain weight was determined

${ }^{\mathrm{z}}$ Means followed by the same uppercase letter within a column are not significantly different. for each individual plant. 
common root rot had no significant detrimental effect on winter wheat forage production, and hypothesized that environmental conditions that were favorable for forage growth but inhibited disease might be responsible for the lack of forage reduction. In the Texas Panhandle, winter wheat grown for forage is typically planted in late August or early September, when temperatures are optimum for disease development. However, in late fall and early spring, when the wheat was sampled for forage production, the temperature is about $7^{\circ} \mathrm{C}$. Under these conditions, wheat can actively grow, but disease development is dramatically limited (16). Even though differences in disease severity were statistically significant, they may not have been biologically significant, especially at the harvest disease evaluation, when all entries exhibited disease ratings greater than 3 .

The observed drought resistance of the closely related plant introductions used in this study and previously described by Lazar et al. (7) was not associated with resistance to common root rot. Furthermore, from the information gathered in this study, common root rot should be of little concern to farmers growing winter wheat in the Texas Panhandle because it had negligible impact on yield components. The minimal effects of common root rot on growth and yield of hard red winter wheat could be due to the environmental conditions previously discussed or to differences in anatomy and development of winter wheat root systems compared with those of spring wheat and barley. Spring wheat has a shorter growing season and less root development than winter wheat. Therefore, spring wheat relies more on the seminal roots for absorption and translocation of water and nutrients. It is easy to see how a diseased subcrown internode could greatly affect nutrient and water translocation to the crown. On the other hand, winter wheat has a large number of nodal roots that grow above the subcrown internode. A deteriorated subcrown internode would have minimal impact on water and nutrients that were delivered to the plants through nodal roots. This could explain why common root rot has had minimal impact on winter wheat forage or grain production in our studies, while researchers working with spring wheat consistently report reduced yields.

\section{LITERATURE CITED}

1. Diehl, J. A., Tinline, R. D., Kochhann, R. A., Shipton, P. J., and Rovira, A. D. 1982. The effect of fallow periods on common root rot of wheat in Rio Grande do Sul, Brazil. Phytopathology 72:1297-1301.

2. Duczek, L. J. 1989. Relationship between common root rot [Cochliobolus sativus] and tillering in spring wheat. Can. J. Plant Pathol. 11:39-44.

3. Duczek, L. J., and Jones-Flory, L. L. 1993. Relationships between common root rot, tillering, and yield loss in spring wheat and barley. Can J. Plant Pathol. 15:153-158.

4. Dusek, D. A., and Musick, J. T. 1992. Deficit irrigation of winter wheat: Southern Plains. ASAE Paper 922608. ASAE, Nashville, TN.

5. Grey, W. E., and Mathre, D. E. 1984. Reaction of spring barley to common root rot and its effect on yield components. Can. J. Plant Sci. 64:245-253.

6. Kokko, E. G., Conner, R. L., Kozub, G. C., and Lee, B. 1995. Effects of common root rot on discoloration and growth of the spring wheat root system. Phytopathology 85:203-208.
7. Lazar, M. D., Salisbury, C. D., and Worrall, W. D. 1995. Variation in drought susceptibility among closely related wheat lines. Field Crops Res. 41:147-153.

8. Ledingham, R. J., Atkinson, T. G., Horricks, J. S., Mills, J. T., Piening, L. J., and Tinline, R. D. 1973. Wheat losses due to common root rot in the prairie provinces of Canada, 196971. Can. Plant Dis. Surv. 53:113-122.

9. Piccinni, G., Rush, C. M., Vaughn, K. M., and Lazar, M. D. 1996. Effects of common root rot on several closely related wheat lines differing for yield response to drought. Agron. Abstr. 72.

10. Rush, C. M., and Mathieson, J. T. 1990. Effects of common root rot on winter wheat forage production. Plant Dis. 74:982-985.

11. Sallans, B. J. 1965. Root rots of cereals. III. Bot. Rev. 31(4):505-536.

12. Specht, L. P., and Rush, C. M. 1988. Fungi associated with root and foot rot of winter wheat and populations of Cochliobolus sativus in the Texas Panhandle. Plant Dis. 72:959-963.

13. Tinline, R. D., Ledingham, R. J., and Sallans, B. J. 1975. Appraisal of loss from common root rot of wheat. Pages 22-26 in: Biology and Control of Soilborne Plant Pathogens. G. W. Bruehl, ed. American Phytopathological Society, St. Paul, MN.

14. Verma, P. R., Morrall, R. A. A., and Tinline, R. D. 1976. The effect of common root rot on components of grain yield in Manitou wheat. Can. J. Bot. 54:2888-2892.

15. Verma, P. R., Morrall, R. A. A., and Tinline, R. D. 1996. The epidemiology of common root rot in manitou wheat IV: Appraisal of biomass and grain yield in naturally infected crops. Can. J. Bot. 59:1656-1665.

16. Wiese, M. V. 1977. Compendium of Wheat Diseases. American Phytopathology Society, St. Paul, MN.

17. Wildermuth, G. B. 1992. Assessment of yield loss caused by common root rot in wheat cultivars in Queensland. Aust. J. Agric. Res. 43:43-58 